\title{
INFLUENCE OF COMBINED FLAKINESS AND ELONGATION INDICES OF COARSE AGGREGATES ON THE BITUMINOUS CONCRETE MIXTURE WITH NMAS OF 12.5MM
}

\author{
Pramukh N ${ }^{1}$, K M Mallesh², Mohammed Ilyas Anjum ${ }^{3}$ \\ ${ }^{I}$ Post Graduate Student, Department of Civil Engineering, Siddaganga Institute of Technology, Tumakuru, Karnataka \\ ${ }^{2}$ Associate Professor, Department of Civil Engineering, Siddaganga Institute of Technology, Tumakuru, Karnataka \\ ${ }^{3}$ Professor, Department of Civil Engineering, Ghousia college of engineering, Ramanagaram, Karnataka
}

\begin{abstract}
In India, approximately 98\% roads are flexible types, probably because of economy. There are two million miles of paved roadways in India. The hot mix asphalt (HMA) is used on approximately $98 \%$ of all paved surfaces. Increasing traffic volumes, tire pressure, and Loading in recent time has place more demand on engineering roads. Technically, a well-designed and constructed road will not only support regional and national development of a country, but also assist in sustaining the life span of the infrastructure. To achieve this, an adequate mix design is essential. Aggregates are one of the key materials used in the construction of the Flexible pavements which they constitute about $95 \%$ in the bituminous mixtures. Aggregate are the largest amount of material that can be found in HMA. Aggregates make up between $80 \%$ to $90 \%$ of total volume or $94 \%$ to $95 \%$ of the mass of hot mix asphalt (HMA). Therefore, aggregate properties are very important in HMA because it will affect the performances of the HMA.

The influence of combined flakiness and elongation indices on Marshall properties of coarse aggregate with NMAS 12.5mm was studied in this paper. Coarse aggregate were manually tested for combined flakiness and elongation indices and were separated under four different percentages(CFIEI 30-35\%, 35-40\%, 40-45\% and 45-50\%). Gradation was fixed as per MoRTH specifications(Upper, middle and lower limit).Optimum bitumen content $(O B C)$ was determined for middle limit gradation with combined flakiness and elongation indices of $30-35 \%$ workability(torque) values were determined at temperatures $90^{\circ} \mathrm{C}, 110^{\circ} \mathrm{C}$ and $130^{\circ} \mathrm{C}$ for three gradation limits with different combined flakiness and elongation indices and graphs were plotted to validate effect of combined flakiness and elongation indices.
\end{abstract}

Keywords: NMAS, Gradation, Optimum bitumen content, Workability.

\section{INTRODUCTION}

Bituminous concrete is a pavement specification composed of a thoroughly controlled hot mixed material having as ingredients i) Graded mineral aggregates, ii)filler and iii)bitumen. It is hot mixed and hot laid and is a superior type of asphaltic pavement. Hence the increasing traffic volume and loading is stressing need to achieve reliability in measuring workability values of bituminous concrete in rational and convenient manner. A new workability device was developed based on previous instruments used to measure workability in concrete and HMA industry. workability with different mixes with different combinations of nominal maximum aggregate size $(12.5 \mathrm{~mm}$ and $19 \mathrm{~mm})$, gradation shape(fine and coarse graded) was tested in temperature range of $120^{\circ} \mathrm{C}$ to $170^{\circ} \mathrm{C}$. Device developed could differentiate mixes based on workability[1]. Three types of paddles code A, B and C were used to validate best suitable paddle for measuring workability. Paddles were tested for seven different mixes. First three mixes(upper, mid and lower graded) with penetration graded 80/100 bitumen and other three with bitumen of penetration grade $60 / 70$ and last one was RAP. Each mix was tested at different speeds 5, 10, 15, 20 and 25 RPM. Paddle B was conclude best based on statistical analysis[2]. Mineral aggregates constitutes approximately $95 \%$ of Hot mix asphalt(HMA) by weight. Cubical particles possessed best rutting resistance over rod, disk and blade shaped aggregates. Flaky and Elongated aggregates in the mixture results in lower resistance to shear deformation[3]. Properties of mineral aggregates have a direct influence on performance of asphaltic pavements. The performance and serviceability of hot mix asphalt pavements are influenced by aggregates particle size, shape and texture[4]. Physical and mechanical properties of asphalt mixtures have a significant impact on pavement stability and reliability during its entire period of its operation. These properties mainly depends on geometric and physical properties of aggregates. The analysis of correlation dependence between geometric and strength indexes of different rock samples shows significant decline of particle strength with increase in number of flat and ablong particles[5]. Flaky aggregates in asphalt mixture influence its marshall properties, including optimum bitumen content. The stability and workability decreases while VMA and asphalt content increases with increase in flaky aggregate content[6]. Three 
different aggregate gradations upper mid and lower limit were adopted and their effect on indirect tensile strength shear strength and rutting parameters on DBM and BC was evaluated[7]. The geometrical cubical shape of aggregate possesses high degree of homogeneity with visible edges and corner faces compared to normal shaped aggregates. Substitution of normal shaped aggregates with geometrically cubical shaped aggregates also produced significant improvement of $22 \%$ to $35 \%$ in aggregate toughness. Dense packing and fewer voids content can also be achieved. Asphalt content will also be lower[8].

\section{MATERIAL CHARACTERIZATION AND METHOOLOGY}

\subsection{Aggregates}

Aggregates used in project work was collected at quarry in Yellapura, Tumkur district. Three aggregate gradations for each type of mix was selected as per MORTH specifications.

- Upper limit of gradation range: The nominal maximum size of this gradation is $9.5 \mathrm{~mm}$ for $\mathrm{BC}$.

- Middle limit of gradation range: The nominal maximum size of this gradation is $13.2 \mathrm{~mm}$ for $\mathrm{BC}$.

- Lower limit of gradation range: The nominal maximum size for this gradation is $13.2 \mathrm{~mm}$ for $\mathrm{BC}$.

Table-1: Proportion of coarse and fine aggregate in each

\begin{tabular}{|l|l|l|l|}
\multicolumn{4}{c}{ gradation range } \\
\begin{tabular}{|l|l|l|} 
Aggregate \\
Gradation
\end{tabular} & $\begin{array}{l}\text { Upper } \\
\text { Limit }\end{array}$ & $\begin{array}{l}\text { Mid } \\
\text { limit }\end{array}$ & $\begin{array}{l}\text { Lower } \\
\text { Limit }\end{array}$ \\
\hline Coarse \% & 29 & 38 & 47 \\
\hline Fine \% & 71 & 62 & 53 \\
\hline
\end{tabular}

Aggregate gradation curve for three gradation ranges is plotted as below:

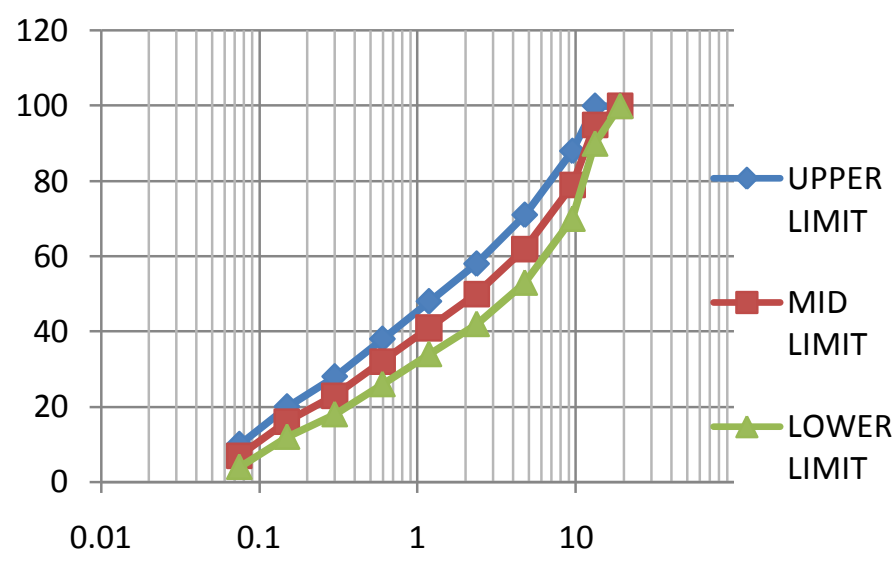

Chart-1: Gradation adopted

Basic properties of aggregates were determined in laboratory and are within the specification in accordance with MORTH.
Table-2: Basic properties of aggregates:

\begin{tabular}{|c|c|c|c|}
\hline $\begin{array}{l}\text { SI. } \\
\text { No }\end{array}$ & Test & Result & $\begin{array}{l}\text { MORTH specification } \\
\text { Limits }\end{array}$ \\
\hline 1 & $\begin{array}{l}\text { Aggregate } \\
\text { Impact value }\end{array}$ & $23.12 \%$ & $24 \% \max$ \\
\hline 2 & $\begin{array}{l}\text { Los Angeles } \\
\text { Abrasion } \\
\text { value }\end{array}$ & $26.49 \%$ & $30 \% \max$ \\
\hline 3 & $\begin{array}{l}\text { Aggregate } \\
\text { Crushing } \\
\text { value }\end{array}$ & $26.76 \%$ & $30 \% \max$ \\
\hline 4 & $\begin{array}{l}\text { Specific } \\
\text { gravity }\end{array}$ & & \\
\hline & $20 \mathrm{~mm}$ down & 2.69 & - \\
\hline & $\begin{array}{l}12.5 \mathrm{~mm} \\
\text { down }\end{array}$ & 2.7 & - \\
\hline & Dust & 2.66 & - \\
\hline 5 & $\begin{array}{l}\text { Water } \\
\text { absorption } \\
(\%) \\
\end{array}$ & & \\
\hline & $20 \mathrm{~mm}$ down & 0.2 & - \\
\hline & $\begin{array}{l}12.5 \mathrm{~mm} \\
\text { down }\end{array}$ & 0.5 & - \\
\hline & dust & 0.85 & - \\
\hline
\end{tabular}

\subsection{Bitumen}

The type of binder used for preparation of bituminous mixture is VG-30 and this was tested for its physical properties and it satisfies all requirements as per MoRTH specification.

Table-3: Properties of VG - 30 grade bitumen

\begin{tabular}{|c|c|c|c|c|}
\hline $\begin{array}{l}\mathrm{Sl} \\
\mathrm{NO}\end{array}$ & Test & Code & Results & \begin{tabular}{l}
\multicolumn{2}{l}{ Requirements } \\
as per \\
MORTH
\end{tabular} \\
\hline 1 & $\begin{array}{l}\text { Penetration } \\
\text { at } 25^{\circ} \mathrm{c} \\
(\mathrm{mm})\end{array}$ & $\begin{array}{l}\text { IS } \\
73: 2006\end{array}$ & 62 & $50-70$ \\
\hline 2 & $\begin{array}{l}\text { Ductility at } \\
25^{\circ} \mathrm{c}(\mathrm{cm})\end{array}$ & $\begin{array}{l}\text { IS } \\
73: 2006\end{array}$ & 95 & Min 75 \\
\hline 3 & $\begin{array}{l}\text { Softening } \\
\text { point }\left({ }^{\circ} \mathrm{c}\right)\end{array}$ & $\begin{array}{l}\text { IS } \\
73: 2006\end{array}$ & 52 & $\operatorname{Min} 47^{\circ} \mathrm{c}$ \\
\hline 4 & $\begin{array}{l}\text { Specific } \\
\text { gravity at } \\
25^{\circ} \mathrm{c}\end{array}$ & $\begin{array}{l}\text { IS } \\
73: 2006\end{array}$ & 1.01 & $0.97-1.02$ \\
\hline 5 & $\begin{array}{l}\text { Flash \& } \\
\text { Fire point } \\
\left({ }^{\circ} \mathrm{c}\right)\end{array}$ & $\begin{array}{l}\text { IS } \\
73: 2006\end{array}$ & $\begin{array}{l}285^{\circ} \mathrm{c} \\
310^{\circ} \mathrm{c}\end{array}$ & $\begin{array}{l}\text { Min } 220^{\circ} \mathrm{C} \\
\operatorname{Min} 270^{\circ} \mathrm{c}\end{array}$ \\
\hline
\end{tabular}




\section{COMBINED FLAKINESS AND ELONGATION}

\section{INDICES}

Aggregate samples were collected from crusher on different days and shape test was carried out. Based on test results they were sorted under four different percentages of Combined Flakiness and Elongation Indices 30-35\%, 35$40 \%, 40-45 \%$ and $45-50 \%$.

\section{OPTIMUM BITUMEN CONTENT (OBC)}

Optimum Bitumen content was determined for Middle limit gradation with Combined Flakiness and Elongation Indices of $30-35 \%$ and results are tabulated:

Table-4: OBC results

\begin{tabular}{|l|l|}
\hline Optimum Bitumen Content & 5.5 \\
\hline Percent Air Voids(\%) & 4.09 \\
\hline Density, g/cc & 2.36 \\
\hline Stability, KN & 22.67 \\
\hline Voids In Mineral Aggregates(VMA) & 16.94 \\
\hline $\begin{array}{l}\text { Percent Voids Filled with } \\
\text { Bitumen(VFB) }\end{array}$ & 75.85 \\
\hline Flow, mm & 2.75 \\
\hline
\end{tabular}

\section{WORKABILITY}

Workability of bituminous mix is ease with which it can be mixed, laid and compacted at workable temperature. Workability of Hot Mix Asphalt(HMA) is critical element in getting desired density of bituminous pavements. Temperature as well as constituents in the mix influences workability of Hot Mix Asphalt. Workability was measured in terms of torque using workability testing machine. This consists of a metallic drum cup shaped at bottom, a shaft attached with blades at bottom edge at different angles, a motor with gearbox, digital ammeter and voltmeter to measure the power required to rotate the mix . Shaft rotation is set to 20rpm . Ammeter and voltmeter readings are noted at different temperatures and torque value is calculated using the equation below:

$$
T=\frac{60 \times O U T P U T \text { POWER }}{2 \times \Pi \times N}
$$

\section{OUTPUT POWER $=1.73 \times \mathrm{V} \times \mathrm{I} \times \mathrm{PF}$}

Where,

$\mathrm{T}=$ Torque $(\mathrm{N}-\mathrm{m})$

$\mathrm{N}=$ Speed

$\mathrm{V}=$ voltmeter value

$\mathrm{I}=$ ammeter value

$\mathrm{PF}=$ power factor $(0.77)$

Workability values calculated for three gradation limits at different temperatures with different Combined Flakiness and Elongation Indices are tabulated and graphs are plotted:
Table-5: Workability results

\begin{tabular}{|c|c|c|c|c|}
\hline CFEI & $\begin{array}{l}\text { Temper } \\
\text { ature } \\
\text { Degree }\end{array}$ & $\begin{array}{l}\text { upper } \\
\text { limit } \\
\text { Torque } \\
\text { N-M }\end{array}$ & $\begin{array}{l}\text { middle } \\
\text { limit } \\
\text { Torque } \\
\mathrm{N}-\mathrm{M}\end{array}$ & $\begin{array}{l}\text { lower } \\
\text { limit } \\
\text { Torque } \\
\text { N-M }\end{array}$ \\
\hline \multirow{7}{*}{$30-35 \%$} & 140 & 31.09 & 38.87 & 46.64 \\
\hline & 130 & 35.76 & 48.20 & 54.42 \\
\hline & 120 & 46.64 & 57.53 & 63.74 \\
\hline & 110 & 55.97 & 65.30 & 77.74 \\
\hline & 100 & 62.19 & 82.40 & 83.96 \\
\hline & 90 & 77.74 & 88.62 & 99.50 \\
\hline & 80 & 90.18 & 93.28 & 107.28 \\
\hline \multirow{8}{*}{$35-40 \%$} & $\begin{array}{l}\text { Temper } \\
\text { ature }\end{array}$ & $\begin{array}{l}\text { upper } \\
\text { limit }\end{array}$ & $\begin{array}{l}\text { middle } \\
\text { limit }\end{array}$ & $\begin{array}{l}\text { lower } \\
\text { limit }\end{array}$ \\
\hline & 140 & 35.75 & 46.64 & 54.41 \\
\hline & 130 & 43.53 & 51.31 & 60.63 \\
\hline & 120 & 49.75 & 57.53 & 66.85 \\
\hline & 110 & 59.08 & 66.85 & 80.85 \\
\hline & 100 & 71.52 & 79.29 & 91.73 \\
\hline & 90 & 87.07 & 97.95 & 105.72 \\
\hline & 80 & 94.84 & 107.28 & 121.27 \\
\hline \multirow{8}{*}{$40-45 \%$} & $\begin{array}{l}\text { Temper } \\
\text { ature }\end{array}$ & $\begin{array}{l}\text { upper } \\
\text { limit }\end{array}$ & $\begin{array}{l}\text { middle } \\
\text { limit }\end{array}$ & $\begin{array}{l}\text { lower } \\
\text { limit }\end{array}$ \\
\hline & 140 & 46.64 & 55.97 & 63.74 \\
\hline & 130 & 57.53 & 65.30 & 76.18 \\
\hline & 120 & 69.96 & 82.40 & 93.28 \\
\hline & 110 & 77.74 & 91.73 & 107.27 \\
\hline & 100 & 94.84 & 110.38 & 124.38 \\
\hline & 90 & 105.72 & 121.27 & 138.37 \\
\hline & 80 & 116.61 & 136.82 & 157.03 \\
\hline \multirow[b]{4}{*}{$45-50 \%$} & $\begin{array}{l}\text { Temper } \\
\text { ature }\end{array}$ & $\begin{array}{l}\text { upper } \\
\text { limit }\end{array}$ & $\begin{array}{l}\text { middle } \\
\text { limit }\end{array}$ & $\begin{array}{l}\text { lower } \\
\text { limit }\end{array}$ \\
\hline & 140 & 69.96 & 80.85 & 93.28 \\
\hline & 130 & 79.29 & 90.18 & 107.28 \\
\hline & 120 & 90.18 & 97.95 & 118.16 \\
\hline
\end{tabular}




\begin{tabular}{|l|l|l|l|l|}
\hline 110 & 99.50 & 119.72 & 127.48 \\
\cline { 2 - 5 } & 100 & 108.83 & 130.60 & 144.59 \\
\cline { 2 - 5 } & 90 & 113.50 & 138.37 & 153.92 \\
\cline { 2 - 5 } & 80 & 127.49 & 147.70 & 169.47 \\
\hline
\end{tabular}

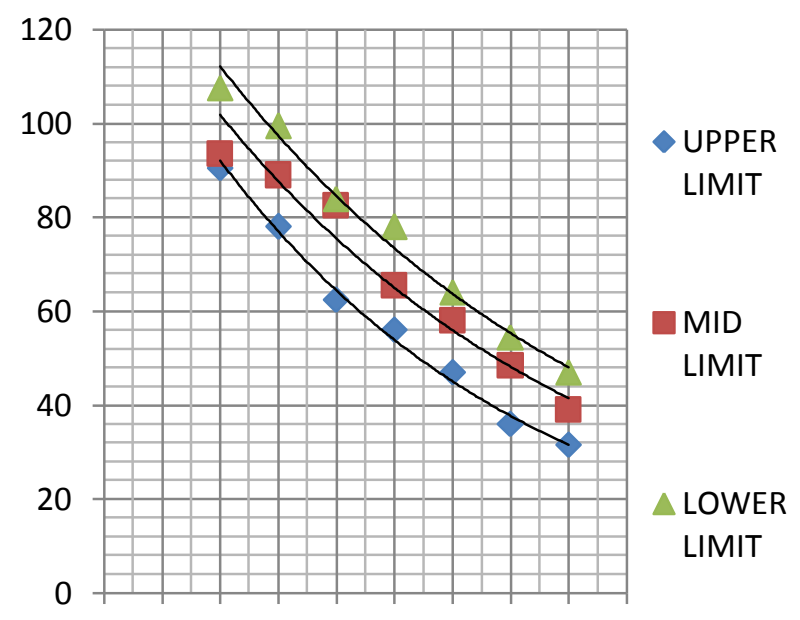

60708090100110120130140150

Chart-2: Torque v/s Temperature 30-35\% CFIEI

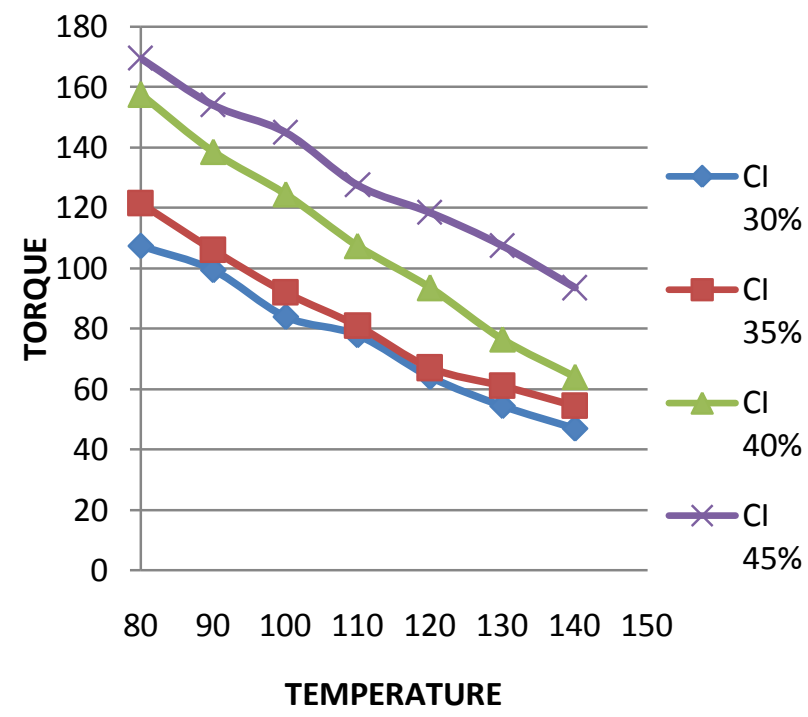

Chart-3: Torque v/s Temperature Lower Limit

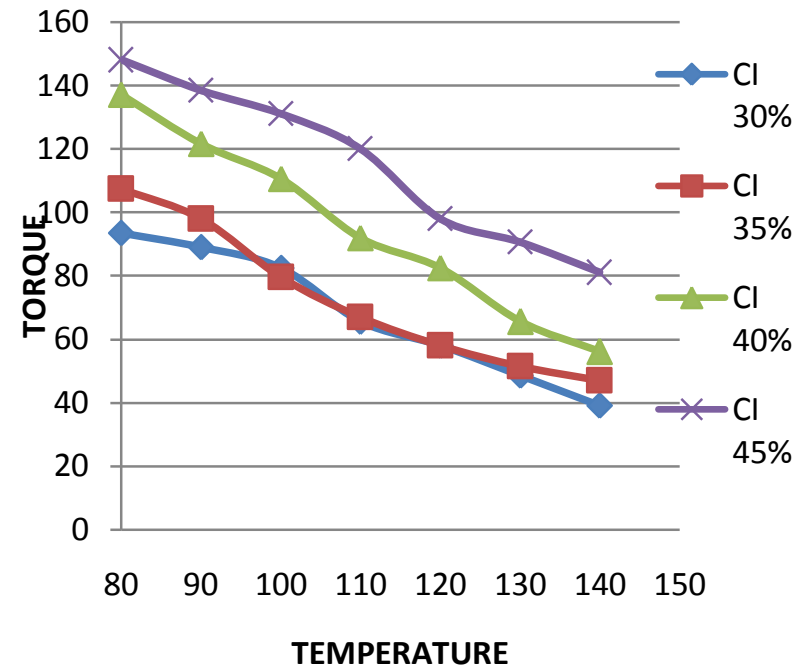

Chart-4: Torque v/s Temperature Mid limit

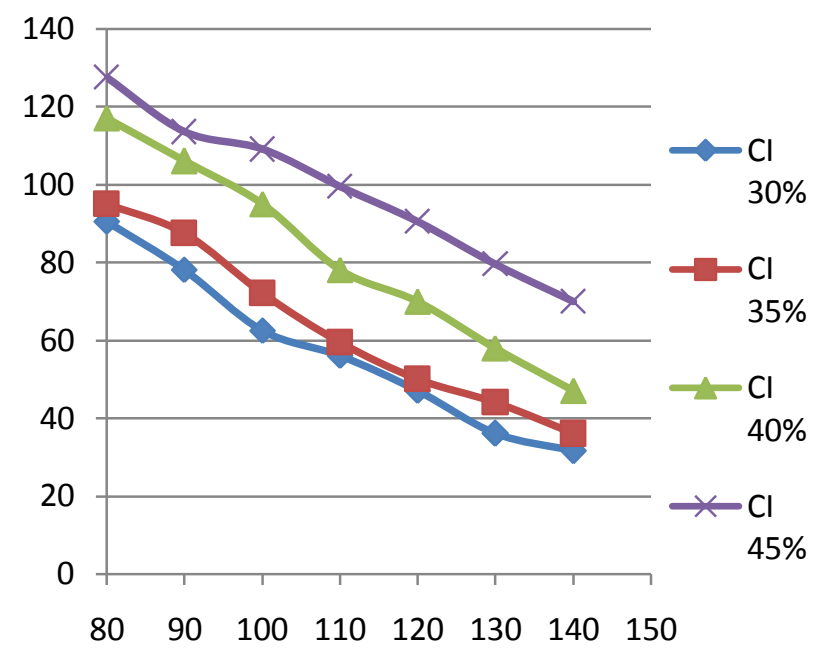

Chart-5: Torque v/s Temperature Upper limit

\section{CONCLUSION}

- Workability values increases with increase in temperature.

- Workability values increases with decrease in Combined Flakiness and Elongation Indices.

- Workability is inversely proportional to Torque values.

\section{ACKNOWLEDGEMENTS}

I would like to thank my guide Mr. K M Mallesh, Associate Professor, HOD \& Staff, Department of Civil Engineering, Siddaganga Institute of Technology, Tumakuru, Karnataka, for their constant encouragement, guidance and support, which enabled me to complete this project.

I would like to thank my parents for their continuous support throughout my life. 


\section{REFERENCES}

[1]. Jagan M Gudimetla, Allen Cooley, Workability of Hot Mix Asphalt, TRB(2003)

[2]. Ahmad Kamil Arshad, Md Diah J, Salah Mohamed Khalil, Developing and Validating HMA Workability Prediction Model for Determining the best paddle as a Machine component for Workability Device, IJEAT, ISSN:2249-8958,Volume-3 (2013)

[3]. Jian-Shiu Chen, K Y Lin, M K Chang, Influence of Coarse Aggregate shape on the strength of Asphalt Concrete Mixtures, Journal of the Eastern Asia Society for Transportation Studies, Vol 6, pp 1062-1075(2005)

[4]. Brown E R, Kandhal P S, Zhang J, Performance Testing for Hot Mix Asphalt, International Journal of Science and Technology, Vol 2, No.1, pp.41-48(2001)

[5]. Matas Bulevicius, Kazys Petkevicious, Stasys Cibra, The Influence of geometric parameters on strength properties of the aggregates used to produce asphalt mixtures, Journal of Civil Engineering and Management, Taylor and Francis(2014)

[6]. Bambang Ismanto, Titi Liliani, Kariantoni Ginting, Workability and Resilient modulusof asphaltic concrete mixtures containing flaky aggregate shape, Journal of the Eastern Asia Society for Transportation Studies, Vol 6, pp 1302-1312(2005)

[7]. Haider Habeeb, Yassir N A Kareem, Satish Chandra, Performance of Bituminous mixes with different aggregate gradations, International Journal of Science and Technology, Vol 2, No.11, (2012)

[8]. Meor Othman Hamzah, Marliana Azura Ahmad Puzi, Khairun Azizi Mohd Azizli, Properties of Geometrically Cubical Aggregates and Its Mixture Design

\section{BIOGRAPHIES}

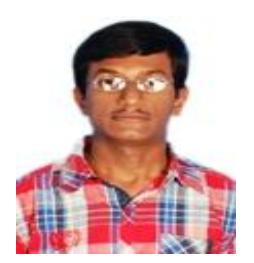

Pramukh N. He is currently studying $\mathrm{M}$ Tech in Transportation Engineering \& Management at Siddaganga Institute of Technology, Tumakuru, Karnataka.

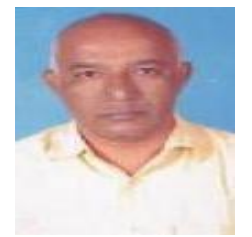

Mallesh $\mathrm{K}$ M is currently working as Associate Professor in Siddaganga Institute of Technology in Civil Engineering Department. He is having a more than 25 years experience in the teaching field and also 5years experience in Highway field. He is also senior Material Engineer in KNR Constructions and he is doing Third party Inspection for PMGSY and Suvarna Grama Road projects.

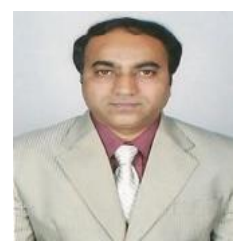

Dr Mohamed Ilyas Anjum is currently working as Vice - Principal \& HoD Civil in Ghousia College of Engineering is having a more than 30 years experience in the teaching field. 